\section{Acquired myasthenia gravis in a dog - a case report}

\author{
Miastenia gravis adquirida em cão - relato de caso
}

\author{
Maria Eduarda dos Santos Lopes Fernandes ${ }^{1}$ (1) , Gabriela Wacheleski Brock ${ }^{2}$ (1), \\ Anna Julia Rodrigues Peixoto ${ }^{1}$ (D), Clarice Gonring Corrêa' (1D, Patricia de Oliveira ${ }^{3}$ (D), \\ Alex Gradowski Adeodato 4 (D) Marta Fernanda Albuquerque da Silva ${ }^{5}$ (1) \& Cássia Maria Molinaro Coelho ${ }^{5}$ (1) \\ 'Veterinary, Doctoral student. Programa de Pós-graduação em Medicina Veterinária - Ciências Clínicas, Universidade Federal \\ Rural do Rio de Janeiro - UFRRJ, Seropédica, RJ, Brasil \\ ²Veterinary, Master's degree student. Programa de Pós-graduação em Medicina Veterinária- Ciências Clínicas, Universidade \\ Federal Rural do Rio de Janeiro - UFRRJ, Seropédica, RJ, Brasil \\ ${ }^{3}$ Veterinary, Msc. Autonomous, Rio de Janeiro, RJ, Brasil \\ ${ }^{4}$ Veterinary, Dsc. CRV Imagem, Rio de Janeiro, RJ, Brasil \\ ${ }^{5}$ Veterinary, Dsc. Departamento de Medicina Veterinária e Cirurgia, Instituto de Veterinária, Universidade Federal Rural do Rio \\ de Janeiro - UFRRJ, Seropédica, RJ, Brasil
}

\begin{abstract}
Neuromuscular diseases are not common in clinical routine of dogs and cats and their diagnosis is a challenge for the veterinarian. This paper reports the clinical diagnosis and the therapy given to a four-year-old mixed-breed female dog with a history of claudication and intermittent paresis, initially in the pelvic limbs and then evolving to the thoracic limbs. Furthermore, there were clinical signs of ataxia and tetraparesis, especially after exercise. Due to the history and clinical signs presented, acquired myasthenia gravis was suspected and the therapeutic diagnosis using anticholinesterase neostigmine was chosen, as it is simple, fast and accessible. The dog presented a significant improvement in clinical status after intramuscular administration of the above mentioned anticholinesterase, and returned to normal ambulatory activity after administration of the drug intravenously, thus enabling the diagnosis of the disease. Treatment was introduced using pyridostigmine bromide $(2.5 \mathrm{mg} / \mathrm{Kg}$, twice a day $)$ associated with corticosteroid in an immunosuppressive dose $(0.5 \mathrm{mg} / \mathrm{Kg}$, twice a day). Both drugs were administered orally for a period of six months, after which there was a complete remission of the clinical signs and there have been no recurrences until now.
\end{abstract}

Keywords: megaesophagus, neuromuscular disorder, neostigmine, veterinary neurology.

\section{Resumo}

Doenças neuromusculares são incomuns na rotina clínica de cães e gatos e o seu diagnóstico é um desafio para o Médico Veterinário. Desta forma, este trabalho relata o diagnóstico clínico e terapêutico em uma cadela sem raça definida de quatro anos com histórico de claudicação e paresia intermitente, inicialmente em membros pélvicos evoluindo para membros torácicos, apresentando sinais clínicos de ataxia e tetraparesia sobretudo após exercício. Em virtude do histórico e sinais clínicos apresentados suspeitou-se de miastenia gravis adquirida, optando-se pelo diagnóstico terapêutico, por ser mais simples, rápido e acessível, utilizando o anticolinesterásico neostigmina. A paciente apresentou melhora significativa no quadro clínico após administração do referido anticolinesterásico por via intramuscular, retornando à atividade deambulatória normal após administração do fármaco por via intravenosa, sendo possível assim o diagnóstico da doença. Foi instituído tratamento utilizando o brometo de piridostigmina (2,5mg/Kg, duas vezes ao dia) associado ao corticosteroide em dose imunossupressora $(0,5 \mathrm{mg} / \mathrm{Kg}$, duas vezes ao dia), ambos por via oral, por um período de seis meses, observando-se remissão completa dos sinais clínicos sem recidivas até o presente momento.

Palavras-chave: megaesôfago, desordem neuromuscular, neostigmina, neurologia veterinária.

\section{Introduction}

Myasthenia gravis (MG) is a disorder caused by a reduced number of functional acetylcholine receptors (AChR) in the post-synaptic membrane of neuromuscular junctions (Batmaz et al., 1998), and may be congenital (MGc) or acquired (MGa) (Sato, 2015). MGc is due to specific genetic mutations that result in a deficiency in AChR (Lindstrom, 2000), and affects puppies between 6 and 12 weeks old. (Shelton, 2002). The acquired form is more common and is an

\section{BJ M \\ Brazilian Journal of Veterinary Medicine \\ p-ISSN 0100-2430 \\ e-ISSN 2527-2179 \\ ○}

How to cite: Fernandes M. E. S. L., Brock, G. W. Peixoto, A. J.R., Corrêa, C. G., Oliveira, P., Adeodato, A. G., Silva, M. F. A., \& Coelho, C. M. M. (2020). Acquired myasthenia gravis in a dog - a case report. Brazilian Journal of Veterinary Medicine, 42 , e106320. doi: 10.29374/2527-2179.bjvm106320

Financial support: This study was financed in part by the Coordenação de Aperfeiçoamento de Pessoal de Nível Superior - Brasil (CAPES) Finance Code 001.

Conflict of interests: No conflict of interests declared concerning the publication of this article.

Received: July 29, 2019

Accepted: March 27, 2020

Thestudy was carried out at Hospital Veterinário, Universidade Federal Rural do Rio de Janeiro UFRRJ, Seropédica, Rio de Janeiro, Brasil.

\section{*Correspondence}

Maria Eduarda dos Santos Lopes Fernandes Universidade Federal Rural do Rio de Janeiro - UFRRJ

Rodovia BR 465, Km 07, s/n, Zona Rural CEP 23890-000 - Seropédica (RJ), Brasil E-mail: dudalopesfer@hotmail.com 
immune-mediated disease in which antibodies (typically class $\mathrm{G}$ immunoglobulins) are produced against AChR (Shelton, 2006).

Acetylcholine is essential for muscle contractions, and a reduced amount of AChR is characterized mainly by muscle weakness and fatigue, especially after exercise. In addition, there may be loss of facial muscle, difficulty in swallowing, megaesophagus and in the most severe cases, secondary aspiration pneumonia (Platt \& Olby, 2004).

The medical history, clinical evaluation, as well as laboratory and complementary exams may be suggestive of MGa; however, they are not conclusive (Taylor, 2010). A radioimmunoassay test (RIA) for the detection of antibodies against AChR is the gold standard for the diagnosis (Shelton, 2002). However, this test is expensive for the guardian of the animal and is not readily accessible for veterinarians in Brazil. Thus, therapeutic diagnosis with anticholinesterase drugs is an important tool in clinical routine (Taylor, 2010); besides, differential diagnoses such as cardiovascular, metabolic and neuromuscular diseases need to be excluded (Lorenz \& Kornegay, 2006). This report describes the diagnostic and therapeutic approach in a dog with clinical signs suggestive of MGa.

\section{Case report}

A 4-year-old mixed breed female dog that was seen at the Veterinary Hospital/UFRRJ, had a history of lameness and had been suffering from intermittent paresis in the pelvic limbs (PL) for 30 days, with progressive evolution to the thoracic limbs (TL) over the latter 15 days. The guardian also reported that the dog had sporadic episodes of regurgitation. At the physical examination, the dog was alert and responsive to stimuli, had a body score of 3/5, vital signs were normal; however, there was marked muscle flaccidity, especially in the PL. The gait assessment revealed ataxia and tetraparesis, in addition to falls after walks. The neurological evaluation confirmed no deficit in cranial nerves, the proprioception tests were unchanged; however, extensor tone was absent and the withdrawal reflexes in the four limbs were weak.

Considering the history, the clinical signs, and the progressive evolution, MGa was suspected. A complete blood count, biochemistry to assess the renal and liver functions, and a contrast radiography of the cervico-thoracic region were requested. The blood count was unremarkable and the contrast radiography ruled out the possibility of megaesophagus; however, the serum biochemistry showed an increase in the enzyme creatine kinase (CK) $(267 \mathrm{U} / \mathrm{L})$. Due to the suspicion of $\mathrm{MGa}$, an anticholinesterase test was performed (neostigmine - $0.5 \mathrm{mg} / \mathrm{lmL}$ ). Before administering the drug, the dog was reluctant to move and had difficulty sustaining her own body weight. However, only 20 minutes after the first administration of $0.04 \mathrm{mg} / \mathrm{kg}$ intramuscularly (IM), she was able to support her own body weight and after 40 minutes she showed significant improvement, and managed to walk a certain distance to her guardian. Subsequently, $0.01 \mathrm{mg} / \mathrm{kg}$ of the drug was administered intravenously (IV) and after just 10 minutes, normal walking activity was observed (Figure 1 - QR code).

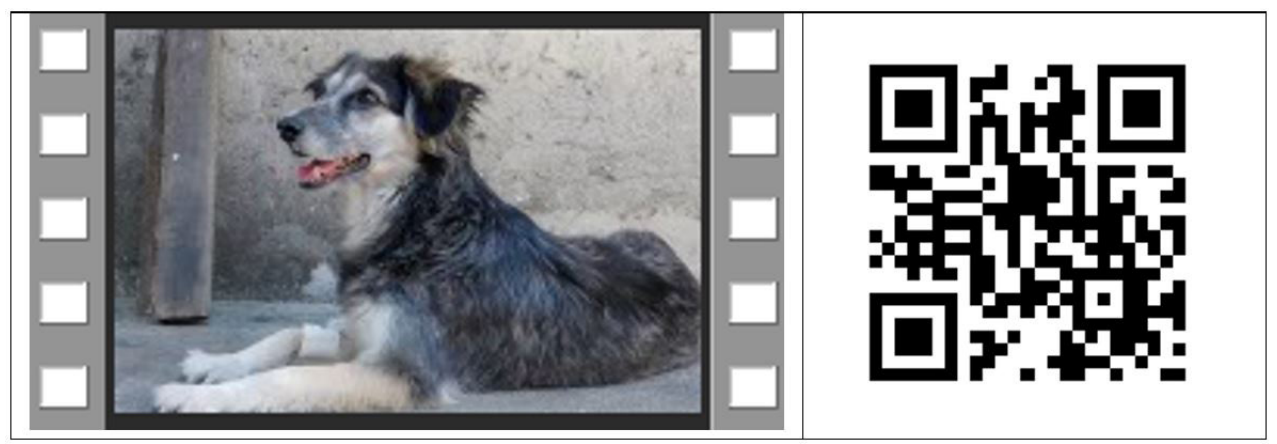

Figure 1. Therapeutic diagnosis and clinical evolution of a dog suspected of having acquired myasthenia gravis. Scan the QR code to watch the video.

After the confirmation of $\mathrm{MGa}, 2.5 \mathrm{mg} / \mathrm{kg}$ of pyridostigmine bromide (Mestinon ${ }^{\circledR}$ ) was prescribed to be taken orally, twice daily as the principal clinical treatment. After a week, the dose was increased to $3 \mathrm{mg} / \mathrm{kg}$; however, due to diarrhea, the $2.5 \mathrm{mg} / \mathrm{kg}$ dose was reintroduced for six months, and 
was associated with $0.5 \mathrm{mg} / \mathrm{kg}$ of prednisone, orally, twice a day for 2 months. Two weeks after the association of the two drugs, the animal was able to walk normally and the guardian of the dog did not report any further episodes of regurgitation. The dog has been in follow-up for one and a half years and there has been no recurrence of the symptoms during this time.

\section{Discussion}

The literature describes the development of MGa in dogs as age-related and is classified as bi-modal, as it can occur between four months and four years old or between 9 and 13 years old (Dewey \& Costa, 2016), which corroborates with our case report in which the animal was four years old. Dickinson et al. (2005) reported that dogs affected by the disease can demonstrate focal weakness, however the generalized presentation, as observed in the dog here, was the classic form, described in 57-64\% of cases (Shelton, 2002), where there are episodes of weakness, primarily in the appendicular muscles and especially after exercise. Selective and persistent weakness can also occur, starting in the PL, which can progressively evolve (Maxie, 2007), as also described in the case report here.

There are no pathognomonic hematological or biochemical abnormalities associated with MGa, but an increase in the CK enzyme may occur, as observed in this report. This increase in CK is due to damage to the myofibrils and muscle membranes, and this may also occur in other situations of myopathies and polymyositis (Dewey \& Costa, 2016). According to Shelton et al. (1997), 90\% of animals who present the generalized form of MGa have megaesophagus, which, however, was not observed in this case, despite the fact that this dog had sporadic regurgitation. Radiographic studies of the cervico-thoracic region are always necessary to assess the presence of megaesophagus, secondary pneumonia and rule out thymoma, since MG can occur as a paraneoplastic syndrome to this mediastinal neoplasia (Sato, 2015).

The clinical, laboratory and radiographic exams did not clarify the reason for the sporadic episodes of regurgitation in the dog in the present report. Therefore, it is possible that the MGa generated motor changes in the esophageal musculature or in the gastroesophageal sphincter (Wray \& Sparkes, 2006) that were then reversed by the early administration of the therapy and thus avoided passive dilation and development of megaesophagus in this case.

The therapeutic diagnosis, via a positive response to the administration of anticholinesterase drugs (Taylor, 2010) can be used as it is fast and has no side effects. Neostigmine bromide is used for therapeutic diagnosis of MGa in dogs at doses of $0.05 \mathrm{mg} / \mathrm{Kg}$, IM, or $20 \mu \mathrm{g} / \mathrm{Kg}$, IV, and clinical improvement is expected in 15 to 30 minutes after administration when applied via IM; however, a faster improvement can be seen in cases of IV administration (Taylor, 2010), as occurred in this report. Administration of anticholinesterase drugs should be carried out with care, since excessive muscle depolarization can cause weakness, respiratory failure, vomiting and diarrhea, especially in non-myasthenic patients (Taylor, 2010). In this case, low doses of neostigmine were used. Moreover, a negative response to the administration of anticholinesterase drugs does not rule out MGa, since clinical improvement will not occur, if the AChR are very low.

According to Shelton (2002), the long-term treatment of MGa is based on the administration of long-acting anticholinesterase drugs, such as pyridostigmine bromide at a dose of 0.5 to $3.0 \mathrm{mg} / \mathrm{kg}$, two to three times a day, orally. In the present case, therapy was started with a dose of $2.5 \mathrm{mg} / \mathrm{kg}$ of pyridostigmine bromide, then increased to $3 \mathrm{mg} / \mathrm{kg}$ after one week, but the dog presented diarrhea, which is one of the possible adverse effects when excessive muscle depolarization occurs due to the use of anticholinesterase drugs. Consequently, the lower dose of pyridostigmine bromide was reintroduced associated with a corticosteroid in an immunosuppressive dose, since an immune-mediated action to the disorder was inferred (Sathasivam, 2008). This association was well tolerated, despite being used over a long term, with no apparent side effects to the animal. Along the six months after the beginning of the treatment, the dosage of the anticholinesterase drug was gradually decreased based on the clinical responses of the animal, and was suspended after complete remission of all clinical signs.

\section{Conclusion}

MGa is a neuromuscular disorder that is little reported in clinical routine, but it should always be a differential diagnosis in animals with muscle weakness and megaesophagus. The conclusive diagnosis of this condition is a challenge for veterinarians, since the therapeutic diagnosis in animals with symptoms that are suggestive of MGa must be considered. 


\section{References}

Batmaz, H., Suzer, F., Kennerman, E., \& Yilmaz, Z. (1998). Myasthenia gravis in a dog. Veterinary and Animal Science, 22, 427-430.

Dewey, C. W., \& Costa, R. C. (2016). A practical guide to canine and feline neurology (3rd ed.). Iowa: Blackwell Publishing.

Dickinson, P. J., Sturges, B. K., Shelton, G. D., \& Lecouteur, R. A. (2005). Congenital myasthenia gravis in smoothhaired miniature dachshund dogs. Journal of Veterinary Internal Medicine, 19(6), 920-923. http://dx.doi. org/10.1111/j.1939-1676.2005.tb02789.x. PMid:16355692.

Lindstrom, J. M. (2000). Acetylcholine receptors and myasthenia. Muscle \& Nerve, 23(4), 454-477. http://dx.doi. org/10.1002/(SICI)1097-4598(200004)23:4<453::AID-MUS3>3.0.CO;2-O. PMid:10716755.

Lorenz, M. D., \& Kornegay, J. N. (2006). Neurologia veterinária (4. ed.). Barueri: Manole.

Maxie, G. (2007). Jubb, Kennedy \& Palmer's Pathology of Domestic Animals Pathology of domestic animals (5th ed.). London: Elsevier.

Platt, S. R., \& Olby, N. J. (2004). BSAVA manual of canine and feline neurology (3rd ed.). Gloucester: British Small Animal Veterinary Association.

Sathasivam, S. (2008). Steroids and Immunosuppressant drugs in myasthenia gravis. Nature Clinical Practice. Neurology, 4(6), 317-327. http://dx.doi.org/10.1038/ncpneuro0810. PMid:18493241.

Sato, W. U. (2015). Afecções do sistema nervoso periférico. In M. M. Jericó, M. M. Kogika \& J. P. Andrade Neto. Tratado de Medicina Interna de Cães e Gatos (pp. 2394) Rio de Janeiro: Roca.

Shelton, G. D. (2002). Myasthenia gravis and disorders of neuromuscular transmission. The Veterinary Clinics of North America. Small Animal Practice, 32(1), 189-206, vii. http://dx.doi.org/10.1016/S0195-5616(03)00085-8. PMid:11785729.

Shelton, G. D. (2006). Immune-mediated muscle diseases: myasthenia gravis and inflammatory myopathies. In Proceedings of the 13th European Society of Veterinary Orthopaedics and Traumatology Congress. Italy: ESVOT.

Shelton, G. D., Schule, A., \& Kass, P. H. (1997). Risk factors for acquired myasthenia gravis in dogs: 1.154 cases (1991-1995). Journal of the American Veterinary Medical Association, 211(11), 1428-1431. PMid:9394894.

Taylor, S. M. (2010). Doenças comumente mediadas pelo sistema imune. In R. W. Nelson \& C. C. Couto. Medicina interna de pequenos animais (4th ed., pp. 1468). Rio de Janeiro: Elsevier.

Wray, J. D., \& Sparkes, A. H. (2006). Use of radiographic measurements in distinguishing myasthenia gravis from other causes of canine megaoesophagus. The Journal of Small Animal Practice, 47(5), 256-263. http://dx.doi. org/10.1111/j.1748-5827.2006.00015.x. PMid:16674720. 